\title{
Reducing postharvest food losses in organic spinach with the implementation of high tunnel production systems
}

\author{
Konstantinos G. Batziakas ${ }^{1}$ (D) - Helena Stanley ${ }^{1} \cdot$ Asterios G. Batziakas $^{2}$ • Jeffrey K. Brecht ${ }^{3}$ - Cary L. Rivard ${ }^{1,4}$. \\ Eleni D. Pliakoni ${ }^{1}$
}

Accepted: 14 October 2020 / Published online: 28 October 2020

(C) INRAE and Springer-Verlag France SAS, part of Springer Nature 2020

\begin{abstract}
Fresh produce constitutes $44 \%$ by weight of the global food losses and waste. Postharvest losses of fresh produce are closely related to the preharvest field conditions during growth. In the Central US, many small acreage vegetable growers are utilizing high tunnels, which have been successful in increasing the yield of several crops. Little is known about the effect of this production system on the postharvest losses. This study tested the hypothesis that the production system will affect the postharvest losses of organic spinach (Spinacia oleracea, "Corvair") when stored at 3 or $13{ }^{\circ} \mathrm{C}$. Comparative open field and high tunnel trials were conducted from 2015 to 2017. Postharvest losses were evaluated with regard to the spinach quality characteristics and shelf life. During storage at $3{ }^{\circ} \mathrm{C}$, there were no major quality differences between the spinach grown in the two production systems. During storage at $13{ }^{\circ} \mathrm{C}$, in both years, spinach grown in the high tunnels had 1.2 to $2.3 \%$ higher water content than spinach grown in the open field. In the second year, high tunnel spinach stored at $13{ }^{\circ} \mathrm{C}$ had a lower respiration rate $(P<0.05)$ and a slower rate of yellowing as indicated by higher chlorophyll content $(P<0.001)$, significantly lower lightness values, and significantly higher hue values than open field spinach. The high tunnel spinach demonstrated longer shelf life in year 1 and higher quality towards the end of storage in year two when compared to open field spinach when stored at $13{ }^{\circ} \mathrm{C}$. This is the first study to examine the effect of the high tunnel production system on the postharvest quality and losses of spinach. Our results indicate that high tunnels can reduce the postharvest food losses of spinach when stored at $13{ }^{\circ} \mathrm{C}$, due to increased water content and decreased senescence rate.
\end{abstract}

Keywords Spinacia oleracea $\cdot$ Protected agriculture $\cdot$ Storage quality $\cdot$ Food security $\cdot$ Leafy greens $\cdot$ Preharvest factors

\section{Introduction}

Global food demand has been increasing, primarily due to the increasing population (Tilman et al. 2011). Concurrently, the constant decrease in natural resources (Suweis et al. 2015) and

Eleni D. Pliakoni

epliakoni@ksu.edu

1 Department of Horticulture \& Natural Resources, Kansas State University, 22201 West Innovation Drive, Olathe, KS 66061, USA

2 Centre of Research and Technology Hellas (CERTH), Information Technologies Institute (ITI), 6th km Harilaou, Thermi Road, 57001 Thessaloniki, Greece

3 Horticultural Sciences Department, University of Florida, 2550 Hull Road, Gainesville, FL 32611, USA

4 Kansas State University Olathe Horticulture Research and Extension Center, 35230 West 135th Street, Olathe, KS 66061, USA the adverse effects of climate change on agricultural production (Campbell et al. 2016) raise concerns about meeting future food demand (Myers et al. 2017; Suweis et al. 2015). Efforts for meeting global food security are mainly focused on increasing the productivity of agricultural systems (Fouilleux et al. 2017; Grafton et al. 2015). However, food losses and waste (FLW) occurring throughout the production and supply chain constitute a substantial problem with regard to global food security (Porat et al. 2018). There are multiple definitions for FLW. Generally, food losses and food waste both involve the reduction of the edible food mass intended for human consumption (Gustavsson et al. 2011). The main difference between food losses and food waste is that losses involve the food being physically lost or inedible while waste involves discarding edible food due to unacceptable quality. Approximately $30 \%$ of the food produced for human consumption is lost (Myers et al. 2017). Fresh fruits and vegetables comprise the biggest portion, covering $44 \%$ by weight of the total food lost or wasted (Lipinsky et al. 2013). 
After detachment from the mother plant, fresh produce deteriorates and its quality progressively decreases. The rate of natural biological deterioration that leads to quality loss is affected by internal and external factors as well as the postharvest conditions and handling (Prusky 2011). Non-optimum storage temperature and humidity, improper packaging, and physical damage during harvesting and handling increase the rate of deterioration and decrease the organoleptic quality of fresh fruits and vegetables (Kader 2005; Prusky 2011). While these losses can be associated with poor handling, consumer rejection, or senescence, the crop postharvest life is mainly determined by its initial quality at harvest (Weston and Barth 1997), which is affected by a variety of preharvest factors (Kader 2000). For non-climacteric commodities, the quality of the crop is the highest possible at the day of harvest and will subsequently decline. Preharvest factors affecting the postharvest quality of fresh produce include genotype selection, environmental conditions, the microclimate during growth, and cultural practices (Kader 2000; Weston and Barth 1997).

Spinach (Spinacia oleracea L.) is a leafy green vegetable of high nutritional value, particularly rich in antioxidants, polyphenols, and flavoinoids (Pandjaitan et al. 2005). Increasing consumer health awareness has led to an increase in spinach consumption and subsequently led to increased production (Morelock and Correll 2008). Spinach is a coolseason crop produced across the USA (Koike et al. 2011). The temperature range for optimum growth of spinach is approximately 16 to $24^{\circ} \mathrm{C}$ (Ernst et al. 2012). The postharvest quality of spinach is significantly affected by the preharvest conditions during growth in the field (Gil 2016; Weston and Barth 1997). For instance, excessive rainfall during spinach growth in the field resulted in a 40\% reduction its shelf life (Johnson et al. 1989). Fresh appearance, tenderness, uniform green color, and absence of defects are main components characterizing high-quality spinach (Cantwell and Kasmire 2002).

Spinach is highly perishable with short shelf life even when stored in optimum conditions (Kader 2002). The high perishability of spinach is attributed to its large surface-to-weight ratio and high respiration rate (Koike et al. 2011). For spinach, optimum storage conditions are $0{ }^{\circ} \mathrm{C}$ and $95-98 \% \mathrm{RH}$ (Suslow and Cantwell 1999). In the Central US, small acreage growers frequently utilize high tunnel systems, and one of the most common cold-season crops grown in these diversified operations is spinach (Buller et al. 2016; Knewtson et al. 2010). Spinach is preferred from these growers because it can be harvested multiple times during the season and also offers increased revenue potential (Orde et al. 2018). However, many of these growers have limited cooling capability and frequently have to store produce at non-optimum temperatures (Greater Kansas City Food Hub Working Group 2015; Watkins and Nock 2012). The main problems associated with spinach storage at non-optimum temperatures are increased rates of water loss and yellowing (Koike et al. 2011). Water loss and yellowing due to chlorophyll breakdown are factors negatively influencing the postharvest quality of spinach (Cantwell and Kasmire 2002). For instance, a $3 \%$ water loss renders spinach unmarketable (Bartz and Brecht 2002). Overall, quality loss reduces consumer acceptability (Shewfelt et al. 2014) which generates a substantial amount of food waste in the fresh produce sector (Baldwin 2002).

A high tunnel is an unheated protected culture structure, typically consisting of a metal frame covered with a single- or double-layer plastic sheet, for the production of horticultural crops (Lamont 2009). There has been an increase in the utilization of high tunnels in the Central US, which has been linked to the rise in the demand of locally produced fruits and vegetables (Jett 2017). The unpredictable weather patterns in the Central US, such as strong winds and excessive rainfall during spring, pose a serious challenge to open field vegetable production (Batziakas et al. 2020a; Hoppenstedt et al. 2019). As a result, a considerable amount of small acreage growers have adopted high tunnel production systems to be able to correspond to the increased demand for local produce (Greater Kansas City Food Hub Working Group 2015). Growers in this region frequently utilize low-input and/or organic production methods in combination with high tunnel production systems (Buller et al. 2016; Greater Kansas City Food Hub Working Group 2015; Knewtson et al. 2010). This production system provides growers with the ability to manipulate the microclimate during crop production (O'Connell et al. 2012; Rogers et al. 2016). High tunnels allow continuous spinach production during the winter season by maintaining the temperature within the growth-conducive range of this crop (Batziakas et al. 2020a; Orde et al. 2018). This production system can increase total yield and reduce the amount of cull spinach (Batziakas et al. 2020a). Spinach produced in high tunnels has bigger leaves and increased water content and in some growing seasons demonstrated increased chlorophyll content and decreased respiration rate (Batziakas et al. 2020a), but with reduced antioxidant content compared to open field production (Batziakas et al. 2020a; Zhao et al. 2007b).

High tunnels can increase the total and marketable yield compared to traditional open field production (Batziakas et al. 2020a; Rogers et al. 2016; Vescera and Brown 2019). This practically means that crop productivity is increased and more marketable product is produced because high tunnels protect the crop from weather-related defects. High tunnels have been successful in reducing the preharvest losses of spinach (Batziakas et al. 2020a). However, the effect of this growing system on postharvest losses of spinach and other horticultural crops, as defined by shelf life and quality deterioration during storage, is unknown. High tunnels have an effect on various fresh produce quality parameters on the day of harvest 
and have been found to affect specifically the physical (Batziakas et al. 2020a), nutritional (Batziakas et al. 2020a; Zhao et al. 2007a, b), and organoleptic quality (Batziakas et al. 2019; Palonen et al. 2017). Crops grown in a protected environment have been reported to be more perishable compared to open field crops, due to the absence of external stress during their development (Hewett 2006). The differences in morphology and composition between the crops produced using open field and high tunnel production systems may affect their postharvest quality and rate of deterioration (Kader 2005).

The overall objective of this work was to compare the effect of high tunnel and open field organic production of spinach (Fig. 1a) on postharvest loss. We evaluated the effect of those production systems on shelf life, physical and nutritional quality of organic spinach during non-optimum temperature storage at $13{ }^{\circ} \mathrm{C}$, and optimum temperature storage at $3{ }^{\circ} \mathrm{C}$ (Fig. 1b).

\section{Materials and methods}

\subsection{Experimental design and plant material}

Spinach (Spinacia oleracea cv. Corvair) was grown at the Kansas State University Olathe Horticulture Research and Extension Center (OHREC) in Olathe, KS, USA. Spinach production was carried out in the open field and in high tunnel systems during a 2-year period: 2015-2016 and 2016-2017.
Both production systems had identical cropping histories since their establishment in 2002. Prior spinach cultivation both high tunnel and open field plots were cover cropped buckwheat which was incorporated to the soil shortly after flowering. The plots followed a "systems" design identical to Hoppenstedt et al. (2019) and Batziakas et al. (2020a). Each production system was replicated six times with each replication consisting of a plot $(6.1 \mathrm{~m} \times 9.1 \mathrm{~m})$ in the open field or in a high tunnel (Fig. 1a). Each of the 6 identical high tunnels used was Quonset style and was exactly the same structure used in Hoppenstedt et al. (2019) and Batziakas et al. (2020a). The cultural practices followed in this experiment are described in Batziakas et al. (2020a) and where the typical organic spinach production practices for the region (Buller et al. 2016). Spinach seed germination occurred in 72-cell trays in a shade house. Organic Neptune's Harvest (Neptune's Harvest, Gloucester, MA, USA) at the recommended rate, $30 \mathrm{ml}$ per 3.81 of water, was used for seedling fertilization. The seedlings were transplanted in the high tunnel and open field after the development of 2-4 true leaves. Transplanting occurring during fall of each year and the spinach was overwintered in the plots. No fertilization was used in the experimental crops except the buckwheat residues. Both production systems were irrigated approximately once per week during the fall, every 2 weeks during the winter, and twice per week during the spring. USDA approved insecticides for organic production, spinosad (Dow AgroSciences; Indianapolis, IN) and azadirachtin (Biosafe Systems, LLC;
Fig. 1 Aerial photo of the experimental plots in Kansas State University Olathe Horticulture Research and Extension Center in Olathe, KS, USA. The open field plots are located on the left and the high tunnel plots on the right (a). Spinach grown in high tunnel (first row) or open field (second row) after 9 days of storage at $13{ }^{\circ} \mathrm{C}$ (left column) and spinach grown in high tunnel or open field after 19 days of storage at $3{ }^{\circ} \mathrm{C}$ (right column) (b)
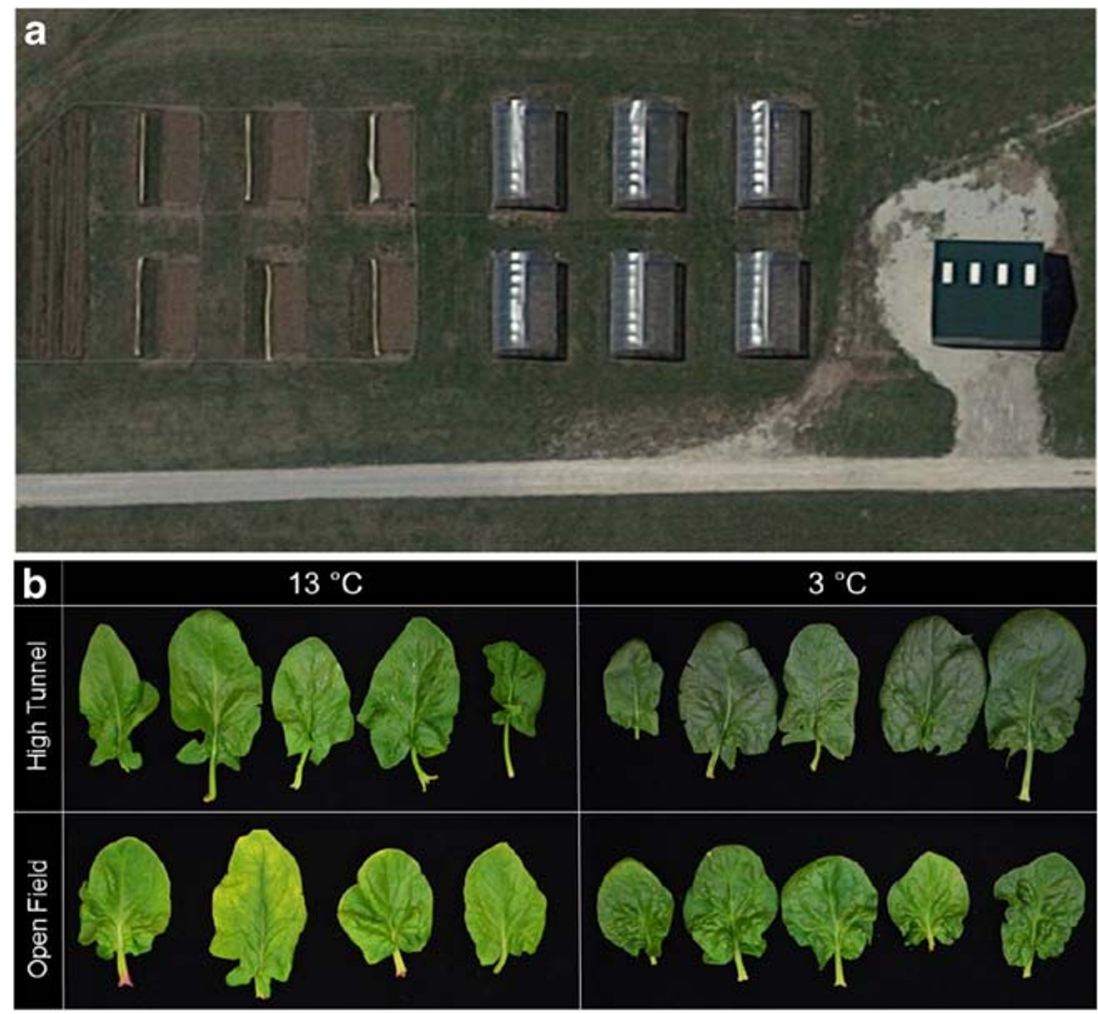
East Hartford, CT, USA), were applied based on the results of typical scouting procedures.

Mature, fully expanded spinach leaves were harvested by hand, which is the common practice for this region, twice (4 December and 16 April) in year 1 (2015-2016) and twice (29 Nov. and 12 April) in year 2 (2016-2017). Leaves with defects such as yellowing, holes, or insect infestation were discarded. After harvest, samples were placed in coolers and immediately transferred to the postharvest physiology lab at the Kansas State University, Olathe campus. After washing 3 times in ice-cold tap water, the spinach was centrifuged using a 5-gal salad spinner for removing excess water (Chef Master 90005, China). Subsequently, the spinach was inspected a second time and defective plant material was discarded. In year 1, the replications per treatment for the shelf life study corresponded to the six field replications per growing system. However, in year 2, the first harvest similarly included six replicates whereas the second harvests consisted of three replications per growing system due to limited supply of spinach from the open field, due to extreme weather conditions. For each growing system, approximately $1 \mathrm{~kg}$ of spinach per replication was packed in produce bags with approximately 10 perforations of $1 \mathrm{~cm}$ diameter to avoid condensation buildup. The bags were stored in environmental chambers (ThermoFisher Scientific Inc., Asheville, NC, USA) in two independent shelf life trials, one at $13{ }^{\circ} \mathrm{C}$ with $95 \% \mathrm{RH}$ and one at $3{ }^{\circ} \mathrm{C}$ with $95 \% \mathrm{RH}$. The non-optimum temperature of $13{ }^{\circ} \mathrm{C}$ is commonly used by local growers in the Central US, for comingling chilling sensitive and non-sensitive crops when access to cooling is limited (Batziakas et al. 2020b). The quality of the spinach was analyzed throughout storage, on days $0,3,5,7$, and 9 for $13^{\circ} \mathrm{C}$, and on days $0,3,9,13,17$, and 19 for $3{ }^{\circ} \mathrm{C}$.

\subsection{Spinach quality analyses}

Physical quality during storage was evaluated by measuring respiration rate, overall visual quality (OVQ), leaf surface color, leaf tenderness, water content, and chlorophyll content.

The respiration rate of the spinach samples was measured using the closed system method (Jacxsens et al. 1999). Approximately 10 spinach leaves per replication were weighed and sealed in air-tight glass jars (0.75 1 Le Parfait, Villeurbanne, France) equipped with a septum, for $60 \mathrm{~min}$. The amount of $\mathrm{CO}_{2}$ that accumulated in the void space of the jar during this period was measured using a portable gas analyzer (Bridge Analyzer; Bedford Heights, OH, USA) and the respiration rate was expressed as the rate of $\mathrm{CO}_{2}$ production in $\mathrm{mg} / \mathrm{kg} \mathrm{h}$.

For each treatment, twenty leaves per replication were evaluated and rated visually, taking into account freshness, appearance, and color uniformity, similarly to Medina et al. (2012), from $9=$ "excellent" to $1=$ "extremely poor" and the limit of product marketability was considered $5=$ "fair". When $30 \%$ of the treatment scored below 5 , the experiment was terminated, marking the end of shelf life (Lareo et al. 2009; Manzocco 2016). All the visual quality ratings were discussed to reach a consensus between two expert judges. Random duplicated visual quality evaluations between judges were performed throughout the experiments to assure the veracity of the scores.

Surface color was measured on leaves using a chromameter (A5 CR-400, Minolta Co. Ltd., Osaka, Japan). For each replication, the color of the adaxial surface of 5 leaves per treatment was measured in 2 spots that were diametrically opposed to the leaf axis. Color parameters were expressed with the CIE L*a*b* color system, $\mathrm{L} *$ is lightness and $\mathrm{h}^{\circ}$ is hue angle, calculated $\operatorname{as}^{-1} \mathrm{~b} * / \mathrm{a}^{*}$ (McGuire 1992).

Leaf tenderness, as resistance to shear force, was measured using a texture analyzer (TA-58, TA.XT.plus, Texture Technologies Corp., Scarsdale, NY, USA), with a 5-blade Kramer Shear Cell (TA-91, Texture Technologies Corp.). Probe return distance was set at $35 \mathrm{~mm}$, test speed at $1.7 \mathrm{~mm} / \mathrm{s}$, and return speed at $10 \mathrm{~mm} / \mathrm{s}$. For each treatment, the midrib of 10 leaves per replication was removed and the leaves were weighed. Peak force required to shear the stack of 10 spinach leaves was measured, similar to Prakash et al. (2000). Leaf tenderness was calculated as the maximum force in Newton per gram.

Water content (WC) of the leaves was measured using $5 \mathrm{~g}$ of fresh leaf tissue that was removed from five randomly selected leaves per replication. The fresh leaf tissue (FW) samples were dried using an oven (Precision ${ }^{\mathrm{TM}}$, Thermo Fisher Scientific, Waltham, MA, USA) set at $80^{\circ} \mathrm{C}$. After $24 \mathrm{~h}$, the dry weight (DW) was measured. The water content was calculated according to Agüero et al. (2008).

The chlorophyll content of the leaves was measured following Wellburn (1994). For each treatment, $0.3 \mathrm{~g}$ of leaf tissue per replication was homogenized in $10 \mathrm{ml}$ of methanol using a benchtop homogenizer (POLYTRON PT 1600 E, Kinematica Inc., Bohemia, NY, USA). The solution was incubated in darkness at $4{ }^{\circ} \mathrm{C}$ for $24 \mathrm{~h}$. Following the incubation, an aliquot of the supernatant was measured at $653 \mathrm{~nm}$ and $666 \mathrm{~nm}$ in a 96-well microplate reader spectrophotometer (Synergy H1, BioTek Instruments, Inc. Winooski, VT, USA). Total chlorophyll content was calculated following Wellburn (1994). The total chlorophyll content was expressed as $\mathrm{mg} / 100 \mathrm{~g} \mathrm{FW}$.

The nutritional quality of the leaves was evaluated by measuring total phenolic content, antioxidant capacity, and vitamin $\mathrm{C}$ content. On each analysis day, spinach leaves were frozen using liquid nitrogen and stored at $-20{ }^{\circ} \mathrm{C}$ for later analysis of the total phenolic content and antioxidant capacity. The frozen samples were freeze-dried using a Harvest Right freeze dryer (North Salt Lake, UT, USA). The freeze-dried samples were pulverized using a pestle and mortar. A solution 
of $20 \mathrm{ml}$ acetone/water $(1: 1 \mathrm{v} / \mathrm{v})$ was used to extract $0.2 \mathrm{~g}$ of freeze-dried spinach powder. The mixture was shaken at $80 \mathrm{rpm}$ for $1 \mathrm{~h}$ using a 2314 multi-purpose rotator (Thermo Fisher Scientific, Waltham, MA, USA) and then centrifuged (JA-17, Beckman Coulter, Palo Alto, CA, USA) at 12,800g at $4{ }^{\circ} \mathrm{C}$ for $20 \mathrm{~min}$. Aliquots of the supernatant were analyzed for total phenolic content and antioxidant capacity. For the vitamin $\mathrm{C}$ measurements, at each day of the shelf life analysis, $2.0 \mathrm{~g}$ of spinach tissue from each experimental unit was homogenized with $20 \mathrm{ml}$ of acid solution (6\% metaphosphoric acid/ $2 \mathrm{~N}$ glacial acetic acid) using a benchtop homogenizer (POLYTRON PT 1600 E, Kinematica Inc., Bohemia, NY, USA) (Klimczak and Gliszczynska-wiglo 2015). The vitamin $\mathrm{C}$ samples were frozen at $-20^{\circ} \mathrm{C}$ for later analysis.

Total antioxidant capacity was measured as the ferricreducing ability of plasma (FRAP) and the oxygen radical absorbance capacity (ORAC) of the samples. FRAP was measured following the procedure of Benzie and Strain (1996). The extracted aliquots were analyzed in a 96-well microplate reader (Synergy H1, BioTek Instruments, Inc. Winooski, VT, USA) at $593 \mathrm{~nm}$ absorbance. FRAP was expressed as micromolar Trolox equivalents on a $100 \mathrm{~g} \mathrm{FW}$ basis ( $\mu \mathrm{mol} \mathrm{TE} /$ $100 \mathrm{~g} \mathrm{FW}$ ).

ORAC was also analyzed spectrophotometrically following Prior et al. (2003). ORAC was expressed as micromolar Trolox equivalent on a $100 \mathrm{~g}$ fresh $\mathrm{FW}$ basis ( $\mu \mathrm{mol} \mathrm{TE} /$ $100 \mathrm{~g} \mathrm{FW}$ ).

The total phenolic content of the samples was measured following Singleton and Rossi (1965). Extracted aliquots were analyzed in a 96-well microplate reader (Synergy H1, BioTek Instruments, Inc. Winooski, VT, USA) at $750 \mathrm{~nm}$ absorbance. The total phenolic content was expressed in $\mathrm{mg}$ gallic acid equivalents on a $100 \mathrm{~g} \mathrm{FW}$ basis (mg GAE/100 g FW).

Vitamin $\mathrm{C}$ content of the samples was measured using ultra-performance liquid chromatography (UPLC) following Klimczak and Gliszczynska-wiglo (2015). On the day of analysis, the frozen samples were thawed and centrifuged at $6177 \mathrm{~g}$ for 10 min (JA-17, Beckman Coulter, Palo Alto, CA, USA). The supernatant was diluted with an acid solution $(6 \%$ metaphosphoric acid/ $2 \mathrm{~N}$ glacial acetic acid) and then filtered using a $0.2 \mu \mathrm{m}$ PTFE syringe filter (VWR International, Radnor, PA, USA). A $5 \mu$ aliquot of the diluted sample was injected in an Acquity Waters UPLC (Waters Corp., Milford, MA, USA) equipped with an Acquity BEH C18 column (Waters Corp., Milford, MA, USA). Flow rate was set at $0.2 \mathrm{ml} / \mathrm{min}$ and the linear gradient of the mobile phase was composed of $5 \mathrm{mM}$ potassium phosphate monobasic $\left(\mathrm{KH}_{2} \mathrm{PO}_{4}\right)$, pH 2.65 with $0.1 \%$ of formic acid (solution $\mathrm{A}$ ) and methanol with $0.1 \%$ of formic acid (solution $\mathrm{B}$ ). The linear gradient of the mobile phase was set at $5-15 \% \mathrm{~B}$ in $1 \mathrm{~min}, 15-35 \% \mathrm{~B}$ in the next $1 \mathrm{~min}$, and returned to initial conditions in $4 \mathrm{~min}$. Vitamin $\mathrm{C}$ was detected at $245 \mathrm{~nm}$ using the Acquity photodiode array detector (PDA) (Waters Corp.,
Milford, MA, USA). The samples were quantified using a 5point standard curve $(2.5-50 \mu \mathrm{g} / \mathrm{ml})$ with purified ascorbic acid (assay percentage range $\geq 99.0 \%$, Fisher Scientific, Hampton, NH, USA) as a standard.

\subsection{Statistical analysis}

All analyses were conducted using statistical language $\mathrm{R}$ (ver 3.4, R Foundation for Statistical Computing, Vienna, Austria). The equality of variance of the data was investigated using Levene's tests and unequal variances were found $(P<0.05)$. The Welch two-way analysis of variance (ANOVA) was used instead of the traditional F-Test ANOVA, to account for the heterogeneous variances (Glass et al. 1972). The benefit is that the ANOVA is not affected by unequal sample size and is also robust against the absence of normality in the residuals of the models, as long as Pearson's moment coefficient of skewness is smaller than 2 (Lix et al. 2008). The dataset was evaluated for skewness and Pearson's moment coefficient was found to be smaller than 2 for the whole set. The data from the years were combined and analyzed using Welch ANOVA with a Holm adjustment to account for unequal variances. Based on the presence of significant interactions between the treatment and year, the data was separated and analyzed per year (Borrelli et al. 2013; Cowan et al. 2014; O'Connell et al. 2012; Orde et al. 2018). For evaluating differences $(P<0.05)$ in the measured quality parameters during shelf life, between the two production years, Welch ANOVA was used with a post hoc pairwise comparison using estimated marginal means with a Holm adjustment.

\section{Results and discussion}

We observed significant interactions between year and production system and year and storage day for the majority of the quality parameters examined in this experiment for both the examined storage temperatures (Table 1). For this reason, each year was analyzed and presented separately for each storage temperature. The observed variation in physical and nutritional quality between the 2 growing seasons examined in this experiment can be attributed to the variation of climatic and environmental conditions between the two growing periods (Tudela et al. 2013). Generally, the climatic conditions in high tunnel systems are highly uncontrollable; however, high tunnels create a microclimate that is conducive for spinach production (Batziakas et al. 2020a). In order to further understand the effect of high tunnel systems on postharvest quality and shelf life, future studies should systematically examine the influence of climatic conditions and environmental variables such as precipitation, air and soil temperature, and light exposure. 
Table $1 \quad P$ values reflecting the effects of year (Y), production system (S), and storage day (D) and their interactions on respiration rate, overall visual quality, leaf color, leaf tenderness, chlorophyll content, water content, total phenolic content, antioxidant capacity, and vitamin $\mathrm{C}$ content of spinach grown in high tunnel or open field from fall 2015 to spring 2017 and stored at $13{ }^{\circ} \mathrm{C}$ for 9 days and $3{ }^{\circ} \mathrm{C}$ for 19 days

\begin{tabular}{|c|c|c|c|c|c|c|c|c|c|c|c|}
\hline Interactions $^{\mathrm{z}}$ & $\begin{array}{l}\text { Respiration } \\
\text { rate }^{\mathrm{y}}\end{array}$ & $\begin{array}{l}\text { Overall visual } \\
\text { quality }\end{array}$ & $\begin{array}{l}\text { Color } \\
\text { hue }\end{array}$ & $\begin{array}{l}\text { Color } \\
\mathrm{L}^{\mathrm{x}}\end{array}$ & $\begin{array}{l}\text { Leaf } \\
\text { tenderness }\end{array}$ & $\begin{array}{l}\text { Chlorophyll } \\
\text { content }\end{array}$ & $\begin{array}{l}\text { Water } \\
\text { content }\end{array}$ & $\begin{array}{l}\text { Total phenolic } \\
\text { content }\end{array}$ & FRAP $^{\mathrm{w}}$ & ORAC $^{\mathrm{v}}$ & $\begin{array}{l}\text { Vitamin C } \\
\text { content }\end{array}$ \\
\hline \multicolumn{12}{|l|}{$13{ }^{\circ} \mathrm{C}$} \\
\hline Year (Y) & $<.05$ & $<.001$ & $\mathrm{NS}^{\mathrm{u}}$ & $<.001$ & $<.001$ & $<.001$ & $<.001$ & $<.001$ & $<.001$ & NS & NS \\
\hline $\begin{array}{l}\text { Production } \\
\text { system (S) }\end{array}$ & $<.001$ & $<.001$ & $<.001$ & $<.001$ & $<.001$ & $<.001$ & $<.001$ & $<.001$ & $<.001$ & $<.001$ & $<.001$ \\
\hline $\begin{array}{l}\text { Storage day } \\
\text { (D) }\end{array}$ & $<.001$ & $<.001$ & $<.001$ & $<.001$ & $<.001$ & $<.01$ & $<.001$ & $\mathrm{NS}^{\mathrm{x}}$ & NS & $<.001$ & $<.001$ \\
\hline $\mathrm{Y} \times \mathrm{S}$ & NS & NS & $<.001$ & $<.001$ & $<.01$ & $<.01$ & $<.01$ & NS & $<.001$ & NS & $<.05$ \\
\hline $\mathrm{Y} \times \mathrm{D}$ & NS & $<.001$ & NS & NS & NS & $<.01$ & NS & NS & $<.05$ & $<.001$ & $<.01$ \\
\hline $\mathrm{S} \times \mathrm{D}$ & NS & $<.05$ & $<.05$ & $<.05$ & NS & NS & NS & NS & NS & NS & NS \\
\hline $\mathrm{Y} \times \mathrm{S} \times \mathrm{D}$ & $<.05$ & NS & NS & NS & $<.05$ & $<.05$ & NS & NS & NS & NS & NS \\
\hline \multicolumn{12}{|l|}{$3{ }^{\circ} \mathrm{C}$} \\
\hline Year (Y) & $<.001$ & $<.001$ & $<.05$ & $<.001$ & $<.001$ & $\mathrm{NS}^{\mathrm{x}}$ & $<.001$ & $<.001$ & $<.001$ & $<0.001$ & $N S^{x}$ \\
\hline $\begin{array}{l}\text { Production } \\
\text { system (S) }\end{array}$ & $<.05$ & $<.05$ & NS & $<.05$ & $<.001$ & NS & $<.001$ & $<.001$ & $<.001$ & $<0.001$ & $<.001$ \\
\hline $\begin{array}{l}\text { Storage day } \\
\text { (D) }\end{array}$ & $<.001$ & $<.001$ & $<.001$ & $<.001$ & $<.001$ & NS & NS & NS & $<.001$ & $<0.001$ & $<.001$ \\
\hline $\mathrm{Y} \times \mathrm{S}$ & NS & NS & $<.05$ & NS & $<.05$ & $<.05$ & $<.01$ & $<.05$ & $<.01$ & NS & $<.001$ \\
\hline $\mathrm{Y} \times \mathrm{D}$ & $<.001$ & $<.001$ & NS & $<.001$ & $<.001$ & NS & NS & NS & NS & $<0.001$ & $<.01$ \\
\hline $\mathrm{S} \times \mathrm{D}$ & NS & NS & NS & NS & NS & NS & NS & NS & NS & NS & NS \\
\hline$Y \times S \times D$ & NS & NS & NS & NS & NS & NS & NS & NS & NS & NS & NS \\
\hline
\end{tabular}

Lack of or poor temperature control is one of the main factors contributing to food losses of fresh fruits and vegetables in the postharvest chain (Jedermann et al. 2014). Temperature dictates the rates of multiple metabolic processes and physiological responses occurring in the plant tissues during storage such as respiration, water loss, physiological breakdown, and compositional changes (Prusky 2011). As a result, non-optimum storage temperature has a detrimental effect on the quality and shelf life of fresh produce (Bartz and Brecht 2002). While the two temperature conditions in this experiment were studied independently and not statistically compared, the spinach stored at $13{ }^{\circ} \mathrm{C}$ had 9-day shelf life (Table 2) and the spinach stored at $3{ }^{\circ} \mathrm{C}$ had 19 -day shelf life (Table 3). Optimum storage temperature remains the most effective approach for reducing postharvest losses (Prusky 2011) and our results are in accordance with this theorem. When observing the quality characteristics of the spinach stored at these two temperatures, there were minimal physical quality differences between the spinach produced in high tunnel and open field during shelf life at $3{ }^{\circ} \mathrm{C}$ (Table 3), but at $13{ }^{\circ} \mathrm{C}$, the spinach from the examined production systems demonstrated differences in its postharvest behavior (Table 2).

\subsection{Quality of spinach stored at $13^{\circ} \mathrm{C}$}

During the 2015-2016 production period (year 1), on the day of harvest, the spinach produced in high tunnels had 1.2 times lower respiration rate $(89.3$ vs $110 \mathrm{mg} \mathrm{CO} / \mathrm{Kg}-\mathrm{h}, P<.0001)$ than the spinach produced in the open field plots (Table 2). Plant respiration is affected by the surrounding plant environment and particularly by abiotic stress such as water stress, ultraviolet (UV) irradiation, and temperature extremes (Plaxton and Podestá 2006). The protective microclimate created in the high tunnel and the fact that its polyethylene cover typically blocks UV light (Espí et al. 2006) might account for the decreased respiration rate at harvest. However, during storage, the respiration rate was similar for the two production systems (Table 2). During the 2016-2017 production period 
Table $2 \quad P$ values reflecting the comparison of respiration rate, overall visual quality, leaf color, leaf tenderness, chlorophyll content, water content, total phenolic content, antioxidant capacity, and vitamin $\mathrm{C}$ content of spinach grown in high tunnel and open field in Olathe, KS, at 2015-2016 (year 1) and 2016-2017 (year 2) and stored at $13{ }^{\circ} \mathrm{C}$ for 9 days

\begin{tabular}{|c|c|c|c|c|c|}
\hline Measurement ${ }^{z}$ & Day 0 & Day 3 & Day 5 & Day 7 & Day 9 \\
\hline & \multicolumn{5}{|l|}{ Year 1} \\
\hline Respiration $^{\mathrm{x}}$ rate & $<.01$ & NS & NS & NS & NS \\
\hline Overall visual quality & $N S^{\mathrm{w}}$ & NS & NS & NS & $<.01$ \\
\hline Color $\mathrm{L}^{\mathrm{v}}$ & NS & NS & NS & NS & NS \\
\hline Color hue & NS & NS & NS & NS & NS \\
\hline Leaf tenderness & NS & NS & NS & NS & NS \\
\hline Chlorophyll content & $<.01$ & NS & NS & NS & NS \\
\hline Water content & $<.01$ & NS & $<.05$ & $<.05$ & .0584 \\
\hline Total phenolic content $\mathrm{t}^{\mathrm{x}}$ & NS & NS & NS & NS & NS \\
\hline FRAP $^{\mathrm{u}}$ & $<.001$ & $<.01$ & $<.001$ & $<.001$ & $<.001$ \\
\hline ORAC $^{t}$ & $<.01$ & $<.01$ & NS & $<.001$ & $<.001$ \\
\hline \multirow[t]{2}{*}{ Vitamin $\mathrm{C}$ content } & NS & $<0.01$ & NS & NS & $<.01$ \\
\hline & \multicolumn{5}{|l|}{ Year 2} \\
\hline Respiration rate & NS & $<.05$ & $<.05$ & $<.05$ & $<.05$ \\
\hline OVQ & NS & NS & NS & $<.01$ & .0515 \\
\hline Color L & NS & $<.05$ & $<.01$ & $<.001$ & $<.001$ \\
\hline Color hue & NS & NS & $<.05$ & $<.01$ & $<.05$ \\
\hline Leaf tenderness & $<.001$ & $<.001$ & NS & NS & NS \\
\hline Chlorophyll content & NS & NS & $<0.001$ & NS & $<0.001$ \\
\hline Water content & $<.001$ & $<.001$ & $<.001$ & $<.001$ & $<.05$ \\
\hline Total phenolic content & $<.01$ & $\mathrm{NS}^{\mathrm{x}}$ & NS & $<.001$ & NS \\
\hline FRAP & NS & NS & NS & NS & NS \\
\hline ORAC & $<.05$ & NS & NS & $<.05$ & $<.01$ \\
\hline Vitamin $\mathrm{C}$ content & NS & NS & NS & NS & NS \\
\hline
\end{tabular}

${ }^{\mathrm{z}}$ In all years, a "systems" experimental design was utilized with six replications per treatment; main treatment effect was high tunnel compared to open field production systems. Each replication represents a spinach plot consisting of an 8.5 -m-long bed with 5 rows each. Only mature leaves were harvested and immature leaves were left on the plant. The harvested spinach was stored at $3{ }^{\circ} \mathrm{C}$ for 19 days. The analysis included 2 harvests per production season

${ }^{y}$ Data are separated by year due to significant interactions observed between the experimental factors

${ }^{\mathrm{x}}$ Welch analysis of variance (ANOVA) was used to test the differences of the examined physical quality parameters between the two production systems $(\alpha=0.05)$

${ }^{\mathrm{w}} N S$ non-significant

${ }^{\mathrm{v}}$ Lightness

${ }^{u}$ Ferric-reducing antioxidant power

${ }^{t}$ Oxygen radical absorbance capacity

(year 2), while the respiration rate did not differ between the two production systems on the day of harvest, spinach produced in the high tunnels had consistently 1.4-1.5 times lower $(P<0.05)$ respiration rate than open field spinach during storage at $13{ }^{\circ} \mathrm{C}$ (Fig. 2). When a crop is subjected to severe environmental stress during growth and particularly close to the period of harvest or/and during harvest, there is a detrimental effect on its postharvest quality due to phenomena like increased respiration, water loss, and decay (Tudela et al. 2013). The negative effect of the preharvest stressors that is not visible during harvest and becomes evident during postharvest storage is described as latent damage (Hung 1993). Prolonged exposure to these stressors can result in higher postharvest oxidative stress (Hodges et al. 2004) and an increased rate of compositional change during storage (Bonasia et al. 2019). This might explain the observed differences between the spinach from the two production systems stored at $13{ }^{\circ} \mathrm{C}$. Excessive rainfall (Hoppenstedt et al. 2019) and strong winds (Zhao and Carey 2009) are common challenges for open field production in the Central US. The high tunnel production system creates a microclimate protected from abiotic stressors such as strong winds, heavy rain, and hail (Zhao and Carey 2009). The spinach grown in the protected microclimate created by the high tunnel is subjected to less abiotic stress during growth than spinach grown in open field. The effect of latent damage on product quality is affected by postharvest exposure to non-optimum temperature (Romig 1995). Thus, when the spinach produced in these two production systems is stored in non-optimum temperature, the stress effect is exacerbated in the open field spinach.

In year 1, spinach grown in the high tunnels had significantly higher water content (approximately 1.5\%) than the spinach grown in the open field plots during the majority of the storage period, but there was no difference between the systems on the last day of shelf life, after 9 days of storage (Fig. 3). In year 2, the water content throughout storage of the spinach grown in the high tunnels was significantly higher (approximately 1.6-2.1\%) than that of the spinach grown in the open field (Fig. 3). Wind exposure and wind speed can increase evapotranspiration in plants (Falamarzi et al. 2014). High tunnels can effectively protect crops from wind exposure (Zhao and Carey 2009), which may explain the consistently increased water content of the high tunnel spinach, at the day of harvest, when compared with the spinach produced in the open field. Batziakas et al. (2020a) also reported that spinach produced in high tunnels consistently demonstrated higher water content at harvest when compared to open field production.

In year 1, there were no differences in leaf tenderness during storage at $13{ }^{\circ} \mathrm{C}$ between the spinach produced in open field plots and high tunnels (Table 2). In year 2 , the spinach produced in the high tunnels had more tender $(P<0.001)$ leaves on the day of harvest until the third day (1.3 vs $1.75 \mathrm{~N} / \mathrm{g}$ ) of storage at $13{ }^{\circ} \mathrm{C}$, but for the rest of the shelf life the leaf tenderness was similar for spinach from the two production systems (Table 2). High tunnels are covered with polyethylene which blocks UV light and UV light exposure has been related to increased leaf thickness (Huché-Thélier 
Table $3 P$ values reflecting the comparison of respiration rate, overall visual quality, leaf color, leaf tenderness, chlorophyll content, water content, total phenolic content, antioxidant capacity, and vitamin $\mathrm{C}$ content of spinach grown in high tunnel or open field in Olathe, KS, at 20152016 (year 1) and 2016-2017 (year 2) and stored at $3{ }^{\circ} \mathrm{C}$ for 19 days

\begin{tabular}{|c|c|c|c|c|c|c|}
\hline Measurement $\mathrm{t}^{\mathrm{z}}$ & Day $0^{\mathrm{x}}$ & Day 5 & Day 9 & Day 13 & Day 17 & Day 19 \\
\hline & Year 1 & & & & & \\
\hline Respiration rate ${ }^{\mathrm{w}}$ & $<.001$ & $\mathrm{NS}^{\mathrm{w}}$ & NS & NS & NS & NS \\
\hline Overall visual quality & NS & NS & $<.01$ & NS & NS & NS \\
\hline Color $\mathrm{L}^{\mathrm{v}}$ & NS & NS & NS & NS & NS & NS \\
\hline Color hue & NS & NS & NS & NS & NS & NS \\
\hline Leaf tenderness & NS & NS & $<.05$ & NS & NS & NS \\
\hline Chlorophyll content & $<.05$ & NS & NS & NS & NS & NS \\
\hline Water content & $<.01$ & $<.01$ & $<.001$ & NS & $<.05$ & NS \\
\hline Total phenolic content & NS & NS & NS & NS & NS & NS \\
\hline FRAP $^{\mathrm{u}}$ & $<.001$ & $<.001$ & $<.001$ & $<.001$ & $<.001$ & $<.001$ \\
\hline ORAC $^{t}$ & $<.01$ & $<.001$ & $<.001$ & $<.05$ & $<.01$ & $<.05$ \\
\hline \multirow[t]{2}{*}{ Vitamin C } & NS & $<.001$ & $<.01$ & $<.05$ & $<.001$ & $<.05$ \\
\hline & Year 2 & & & & & \\
\hline Respiration rate & NS & NS & NS & NS & NS & NS \\
\hline Overall visual quality & NS & NS & NS & NS & NS & NS \\
\hline Color L & NS & NS & NS & NS & NS & NS \\
\hline Color Hue & NS & NS & NS & NS & NS & NS \\
\hline Leaf tenderness & $<.05$ & NS & NS & NS & $<.05$ & $<.01$ \\
\hline Chlorophyll content & NS & NS & $<0.05$ & $<0.01$ & NS & NS \\
\hline Water content & $<.001$ & $<.001$ & $<.01$ & $<.001$ & $<.001$ & $<.001$ \\
\hline Total phenolic content & .001 & $<.05$ & $<.05$ & NS & $<.01$ & $<.001$ \\
\hline FRAP & NS & NS & NS & NS & NS & NS \\
\hline ORAC & NS & NS & NS & NS & $<0.05$ & NS \\
\hline Vitamin C & NS & NS & NS & NS & NS & NS \\
\hline
\end{tabular}

${ }^{\mathrm{z}}$ In all years, a "systems" experimental design was utilized with six replications per treatment; main treatment effect was high tunnel compared with open field production systems. Each replication represents a spinach plot consisting of an 8.5 -m-long bed with 5 rows each. Only mature leaves were harvested and immature leaves were left on the plant. The harvested spinach was stored at $3{ }^{\circ} \mathrm{C}$ for 19 days. The analysis included 2 harvests per production year

${ }^{y}$ Data are separated by year due to significant interactions observed between the experimental factors

${ }^{\mathrm{x}}$ Welch analysis of variance (ANOVA) was used to test the differences of the examined physical quality parameters between the two production systems $(\alpha=0.05)$

${ }^{\mathrm{w}} N S$ non-significant

${ }^{\mathrm{v}}$ Lightness

${ }^{\mathrm{u}}$ Ferric-reducing antioxidant power

${ }^{\mathrm{t}}$ Oxygen radical absorbance capacity et al. 2016) which may explain the tenderness in spinach leaves produced in the high tunnels.

Spinach produced in the high tunnels had higher chlorophyll content $(P<0.01)$ than open field spinach $(114.2 \mathrm{vs} 91 \mathrm{mg} /$ $100 \mathrm{~g} \mathrm{FW}$ ) on the day of harvest in year 1 , but there were no differences between the two production systems during the 9 days of storage (Table 2). UV light exposure might account for the decreased chlorophyll content (Huché-Thélier et al. 2016) of the spinach produced in the open field. The inconsistent behavior of leaf tenderness and chlorophyll content could be a result of the inter-annual variation in solar radiation including UV radiation and their interaction with other variable climatic factors such as air temperature (Ballaré et al. 2011). In the second year of the experiment, there were no differences in chlorophyll content on the day of harvest between the two production systems (101.1 vs $93.3 \mathrm{mg} / 100 \mathrm{~g} \mathrm{FW}$ ) (Table 2). However, the spinach produced in the high tunnels had 1.4 times higher $(P<0.001)$ chlorophyll content after 9 days of storage than the open field spinach $(129.5 \mathrm{vs} 91.5 \mathrm{mg} / 100 \mathrm{~g}$ FW) (Table 2). In year 1, there were no differences in leaf color during storage at $13{ }^{\circ} \mathrm{C}$ between the spinach produced in open field plots and high tunnels (Table 2). In year 2, after 3 days of storage until the end of storage life, the spinach produced in the high tunnels had consistently significantly darker leaves than the spinach produced in the open field plots (Fig. 2). In addition, the spinach produced in the high tunnels had significantly higher 
Fig. 2 Respiration rate (a), oxygen radical absorbance capacity (ORAC) (b), leaf color, hue (c), and lightness (d) of spinach grown in high tunnel or open field in Olathe, KS, 20162017 (year 2) and stored at $13{ }^{\circ} \mathrm{C}$ for 9 days. Each value represents the mean $( \pm \mathrm{SD})$ of measurements obtained from two harvests
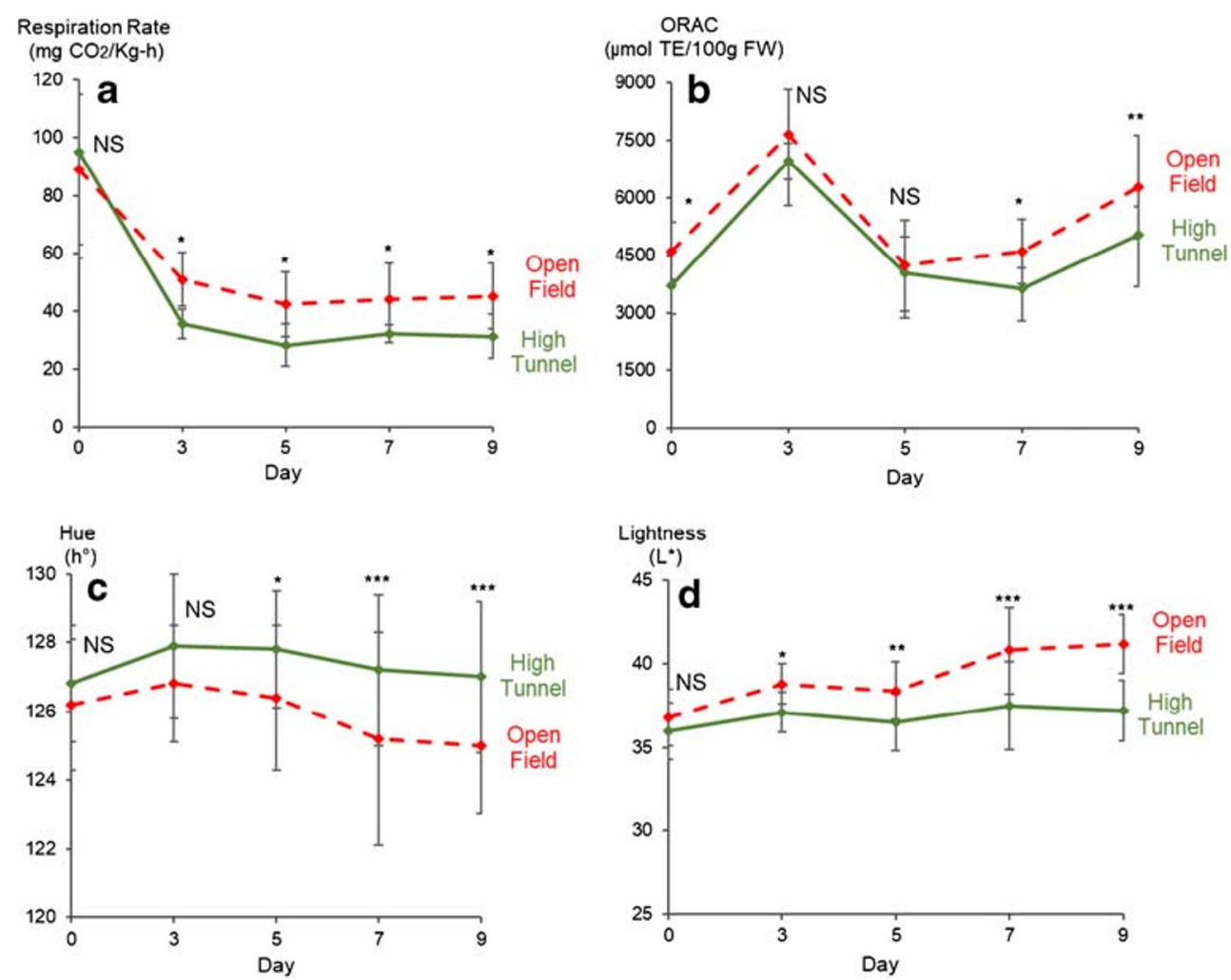

hue values after 5 days of storage at $13{ }^{\circ} \mathrm{C}$, until the end of the shelf life (Fig. 2). Dark green spinach leaf color is directly associated with freshness (Martínez-Sánchez et al. 2019). In spinach, leaf chlorophyll breakdown and color change have been directly related to reactive oxygen species (ROS)-regulated senescence (Yamauchi and Watada 1991) and all of these phenomena are accelerated by non-optimum storage temperature (Pandrangi and LaBorde 2004). The spinach produced in the high tunnels had lower respiration rates during storage. This indicates a slower senescence rate accompanied with a slower rate of chlorophyll breakdown when compared with the open field produced spinach. The difference in chlorophyll breakdown between the two production systems during shelf life at $13{ }^{\circ} \mathrm{C}$ was more evident when examining leaf hue and lightness than leaf chlorophyll content. This discrepancy between leaf color measurements and chlorophyll content might be related to the uneven and patchy chlorophyll loss in spinach leaves (Bergquist et al. 2006). Moreover, the colorimeter measures only small areas of the crop (an 8-mm diameter circle) while the chlorophyll analysis involves a more homogenous mixture of plant tissue (Proulx et al. 2010).

The quality and postharvest losses of leafy greens are primarily defined by the rate of water loss and chlorophyll breakdown induced yellowing during storage (Cantwell and Kasmire 2002). Our results indicate that the high tunnel production system can reduce the postharvest food losses of spinach when stored in nonoptimum temperature such as $13{ }^{\circ} \mathrm{C}$, as evaluated by these parameters. The combination of higher water content with a slower rate of yellowing when stored at $13^{\circ} \mathrm{C}$ resulted in higher overall visual quality and longer shelf life for high tunnel spinach compared with the spinach produced in the open field (Table 2). In year 1 , the overall visual quality of spinach stored at $13{ }^{\circ} \mathrm{C}$ did not differ significantly between the two production systems during the majority of the storage life except on the last day of storage (Table 2). Specifically, after 9 days of storage the spinach produced in the high tunnels had significantly higher $(P<0.01)$ overall visual quality than the spinach produced in the open field plots (5.8 vs 5.4) (Table 2). In year 2, after 7 days of storage, spinach produced in the high tunnels had significantly higher $(P<0.01)$ overall visual quality than spinach produced in the open field (5.8 vs 5.1) (Table 2). While on the last day of storage the high tunnel spinach demonstrated higher overall visual quality compared to the open field spinach (4.8 vs 4.3 ), the difference was not significant $(P=0.051)$ (Table 2$)$.

Postharvest food losses do not only involve physical quality characteristics that are visible to the consumer but also include the deterioration of nutritional quality (Kader 2005). With regard to the nutritional quality of the spinach, for both years of the experiment, there was no difference between the phenolic content of spinach produced in the high tunnels and open field plots during shelf life at $13{ }^{\circ} \mathrm{C}$ (Table 2). During year 1 , the spinach grown in the high tunnels had throughout storage significantly lower antioxidant capacity in terms of FRAP and ORAC (Fig. 4). Specifically, spinach grown in the high tunnels had 1.5-1.6 times lower FRAP and 1.2-1.4 times lower ORAC than open field spinach (Fig. 4). In year 2, 
Fig. 3 Water content of spinach grown in high tunnel or open field in Olathe, KS, at 2015-2016 (year 1) and 2016-2017 (year 2) and stored at $13{ }^{\circ} \mathrm{C}$ for 9 days (a) and $3{ }^{\circ} \mathrm{C}$ for 19 days (b). Each value represents the mean $( \pm \mathrm{SD})$ of measurements obtained from two harvests
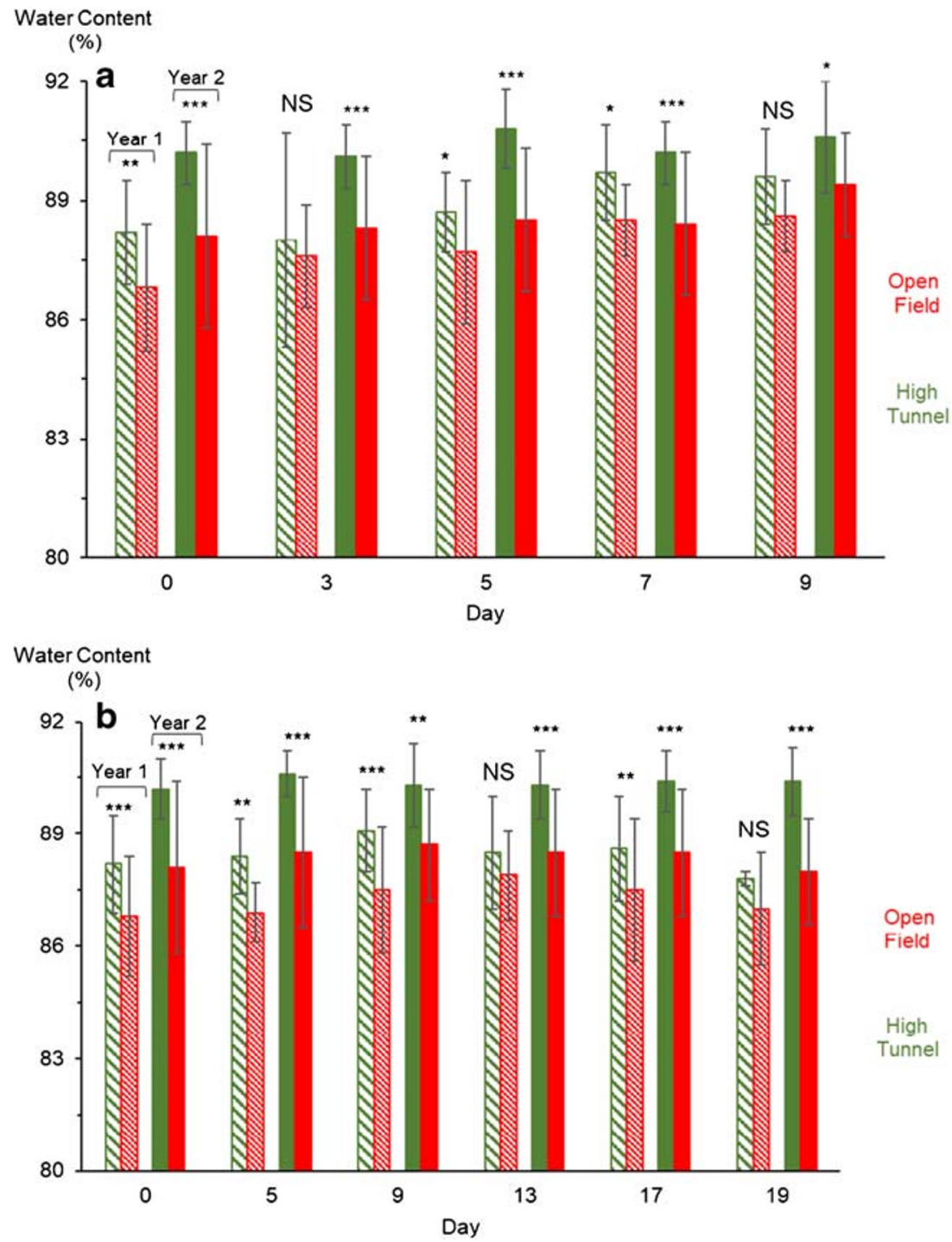

there were no differences in the FRAP values between the two production systems (Table 2). However, spinach produced in the high tunnels had 1.2 times lower $(P<0.05)$ ORAC value on the day of harvest than open field spinach (Fig. 2). On days 3 and 5 of storage, there were no differences in ORAC values between the two production systems, but at the end of shelf life, high tunnel spinach had significantly lower $(P<0.01)$ ORAC values than the open field spinach (1.3 times lower) (Fig. 2). Similar to our results, Zhao et al. (2007b) and Batziakas et al. (2020a) reported that high tunnels produced
Fig. 4 Oxygen radical absorbance capacity (ORAC) (a) and ferric-reducing antioxidant power (FRAP) (b), of spinach grown in high tunnel or open field in Olathe, KS, 2016-2017 (year 1) and stored at $13{ }^{\circ} \mathrm{C}$ for 9 days. Each value represents the mean $( \pm \mathrm{SD})$ of measurements obtained from two harvests
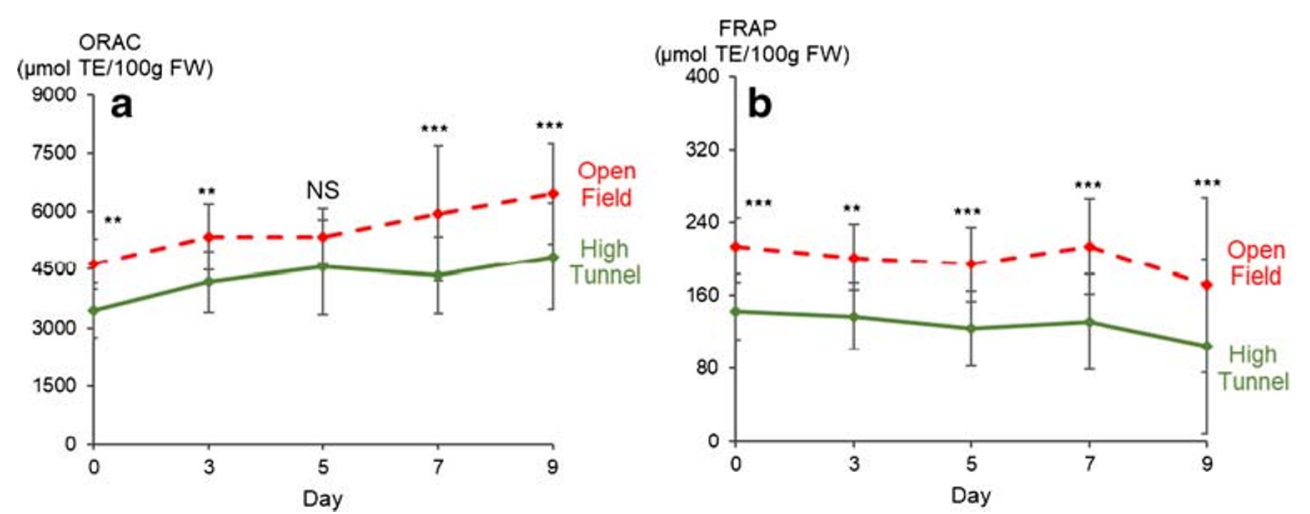
spinach with lower antioxidant capacity. In vegetables, increased antioxidant capacity and phenolic content have been linked with the response of the secondary metabolism to exposure to abiotic stressors such as UV light, water stress, and extreme temperature (Cisneros-Zevallos 2003). In year 1, vitamin $\mathrm{C}$ content did not differ between the two production systems on the day of harvest (631.5 vs $704.4 \mu \mathrm{g} \mathrm{AA} / \mathrm{g}$ FW). However, after 9 days of storage at $13{ }^{\circ} \mathrm{C}$, the high tunnel produced spinach had significantly lower $(P<0.01)$ vitamin $\mathrm{C}$ content than the open field produced spinach (458.3 vs $610.4 \mu \mathrm{g} \mathrm{AA} / \mathrm{g} \mathrm{FW}$ ) (Table 2). In the second year of the experiment, there were no differences in vitamin $\mathrm{C}$ content between the two production systems (Table 2). In spinach, increased vitamin $\mathrm{C}$ at harvest has been linked with improved visual quality (Bergquist et al. 2006) and a decreased rate of vitamin $\mathrm{C}$ degradation is linked to slower senescence rate (Hodges and Forney 2003) during storage. However, the behavior of antioxidant capacity is not always correlated with postharvest behavior of fresh produce and quality loss is not necessarily associated with a reduction of antioxidant concentration (Hodges and DeLong 2007). In our experiment, while spinach produced in the high tunnels demonstrated reduced phenolic content, antioxidant capacity, and vitamin $\mathrm{C}$, it retained its quality for longer or it had similar quality as the open field spinach.

\subsection{Quality of spinach during storage at $3{ }^{\circ} \mathrm{C}$}

During the 2015-2016 production period (year 1), the respiration rate on the day of harvest of the spinach produced in the high tunnels was 1.2 times lower compared to the open field $(P<.0001)(89.3$ vs $110.0 \mathrm{mg} \mathrm{CO} / \mathrm{Kg}-\mathrm{h})$ (Table 3$)$. However, during storage at $3{ }^{\circ} \mathrm{C}$, there was no difference in respiration rate between the two production systems (Table 3 ). One of the main benefits of cooling fresh produce is that it rapidly reduces their respiration rate (Watkins and Nock 2012). Similarly, in the 2016-2017 production period (year 2 ), the respiration of spinach was similar for both growing systems at harvest and throughout the storage life (Table 3). In year 1, spinach grown in the high tunnels had significantly higher water content (approximately 1-1.4\%) during most of the storage period than the spinach grown in the open field (Fig. 3), but there was no difference between the two systems on the last day of shelf life (Fig. 2). In year 2, spinach grown in the high tunnels had significantly higher water content throughout storage (approximately $1.2-2.3 \%$ ) than the spinach grown in the open field plots (Fig. 3). Leafy green crops with increased water content and reduced respiration rate indicate reduced stress and a crop with a potential for longer shelf life (Gil 2016). However, optimum storage temperature typically minimizes the oxidative stress (Toivonen 2003). As a result, while spinach produced in the high tunnel demonstrated decreased stress at harvest, the two systems demonstrated similar postharvest behavior and crop quality during storage at $3{ }^{\circ} \mathrm{C}$. In the first year of the experiment, the spinach grown in the high tunnels had similar visual quality as the spinach grown in the open field, with one exception. We observed significantly higher visual quality $(P<0.01)$ after 9 days of storage for the spinach grown in the high tunnels when compared to spinach produce in the open field plots ( 7.2 vs 6.8) (Table 3). In year 2, there were no significant differences in overall visual quality between the two production systems at harvest and during storage (Table 3). Our results align with the fact that optimum temperature is the most effective postharvest tool for reducing losses (Prusky 2011).

In year 1, spinach grown in the high tunnels had significantly more tender leaves $(P<0.01)$ after 9 days compared to the spinach grown in the open field plots ( $1.37 \mathrm{vs} 1.62 \mathrm{~N} / \mathrm{g}$ ), but the leaf tenderness was similar between the production systems for the rest of the storage period (Table 3 ). In year 2 , spinach grown in the high tunnels had leaves that were significantly more tender than open field spinach $(1.3 \mathrm{vs} 1.76 \mathrm{~N} / \mathrm{g}, P<0.05)$ on the day of harvest. No differences were observed in leaf tenderness during the majority of the storage period (Table 3), but at the end of the shelf life, spinach grown in the high tunnels had significantly more tender leaves than open field spinach on day $17(1.24$ vs $1.73 \mathrm{~N} / \mathrm{g}, P<0.05)$ and day $19(1.18 \mathrm{vs} 1.86 \mathrm{~N} /$ g, $P<0.01)$. High tunnel spinach demonstrated consistently higher water content during storage, which, in leafy vegetables is directly related to their textural properties (Sams 1999). However, the spinach grown in the two production systems did not demonstrate many differences in leaf tenderness, during storage at both temperatures. This difference between the production systems with regard to water content and tenderness might be attributed to the fact that the open field produced thicker spinach leaves while the high tunnel produced leaves with thinner cell walls consistent with higher water content, which implies lower dry matter content (Batziakas et al. 2020).

In the first year of the experiment, the chlorophyll content of spinach produced in the high tunnels was significantly higher $(P<0.05)(114.2 \mathrm{vs} 91.1 \mathrm{mg} / 100 \mathrm{~g} \mathrm{FW})$ on the day of harvest than that of the spinach produced in the open field (Table 3). Light intensity and light quality during growth affects the quality of leafy greens (Gil 2016; Weston and Barth 1997) and particularly the leaf pigmentation. Exposure to UVB light can reduce the photosynthetic activity of spinach (Iwanzik et al. 1983) and decrease chlorophyll content (Huché-Thélier et al. 2016). This may explain the increased chlorophyll content of spinach produced in the high tunnels compared with the open field spinach at the day of harvest. In year 1, there was no difference in chlorophyll content between the two production systems during the storage life (Table 3 ). In year 2, spinach produced in high tunnels had significantly higher chlorophyll content after 9 (102.1 vs $84.6 \mathrm{mg} / 100 \mathrm{~g}$ FW, $P<0.05)$ and 13 days $(117.8 \mathrm{vs} 102.7 \mathrm{mg} / 100 \mathrm{~g} \mathrm{FW}$, $P<0.01$ ) of storage (Table 3 ) than the spinach grown in the 
open field plots. In both years, there were no significant differences in leaf color between the spinach produced in the high tunnels and the open field plots (Table 3).

During the first experimental season, total phenolic content did not differ between high tunnel and open field systems during storage at $3{ }^{\circ} \mathrm{C}$ (Table 3 ). However, in year 2, spinach grown in the high tunnels had significantly lower phenolic content from the day of harvest to the end of shelf life than the spinach produced in the open field plots (Fig. 5). Specifically, spinach grown in the high tunnels had 1.3-2 times lower phenolic content during storage than open field spinach (Fig. 5). In year 1, the antioxidant capacity (FRAP \& ORAC) of the spinach grown in the high tunnels was significantly lower than in open field spinach on the day of harvest and throughout the storage life when stored at $3{ }^{\circ} \mathrm{C}$ (Table 2). Specifically, spinach grown in the high tunnels had 1.4-1.7 times lower FRAP and 1.2-1.6 times lower ORAC (Fig. 5). In contrast to the first production year, during the second year, there was no significant difference during storage life in the antioxidant capacity of the spinach produced in the two production systems (Table 3 ). In year 1 , there was no difference in vitamin $\mathrm{C}$ content between the two production systems on the day of harvest; however, high tunnel spinach had significantly lower vitamin $C$ content throughout the rest of shelf life (Fig. 5). Specifically, spinach grown in the high tunnels had 1.2-1.3 times lower vitamin $\mathrm{C}$ content during storage life than open field spinach (Fig. 5). On the other hand, in year 2, there were no significant differences in vitamin $\mathrm{C}$ content, between the two production systems (Table 3 ). Overall, during shelf life, the spinach produced in the high tunnels had lower nutritional quality compared to open field spinach as indicated by total phenolic content, antioxidant capacity, and vitamin C content for both of the examined temperatures. However, the total phenolic content (Asfi et al. 2012), ORAC (Haytowitz and Bhagwat 2010), FRAP (Machado et al. 2018), and vitamin C (Bergquist et al. 2006) values measured for the high tunnel spinach were still within ranges that have been previously reported for spinach.

This is the first study to examine the effect of the high tunnel production system on the postharvest quality and losses of spinach. Recent reports highlight further the ability of high tunnels to reduce food losses and contribute towards global food security. High tunnel spinach production reduces the preharvest losses of this crop, as the result of increased productivity, marketability, and premium harvest quality (Batziakas et al. 2020). Consumer dissatisfaction is a major factor contributing to postharvest food waste (Kader 2005). In a blind consumer study, the spinach produced in high tunnels was preferred compared to spinach grown in the open field in terms of overall liking, flavor, and texture (Batziakas et al. 2019). All the above indicate that high tunnels are a growing system that can be utilized for meeting fresh produce demand
Fig. 5 Oxygen radical absorbance capacity (ORAC (a) and ferric-reducing antioxidant power (FRAP) (b), and vitamin C (c) of spinach grown in high tunnel or open field in Olathe, KS, 2016-2017 (year 1), and total phenolic (d) content of spinach grown in high tunnel or open field in Olathe, KS, 2016-2017 (year 2) and stored at $3{ }^{\circ} \mathrm{C}$ for 19 days. Each value represents the mean $( \pm \mathrm{SD})$ of measurements obtained from two harvests
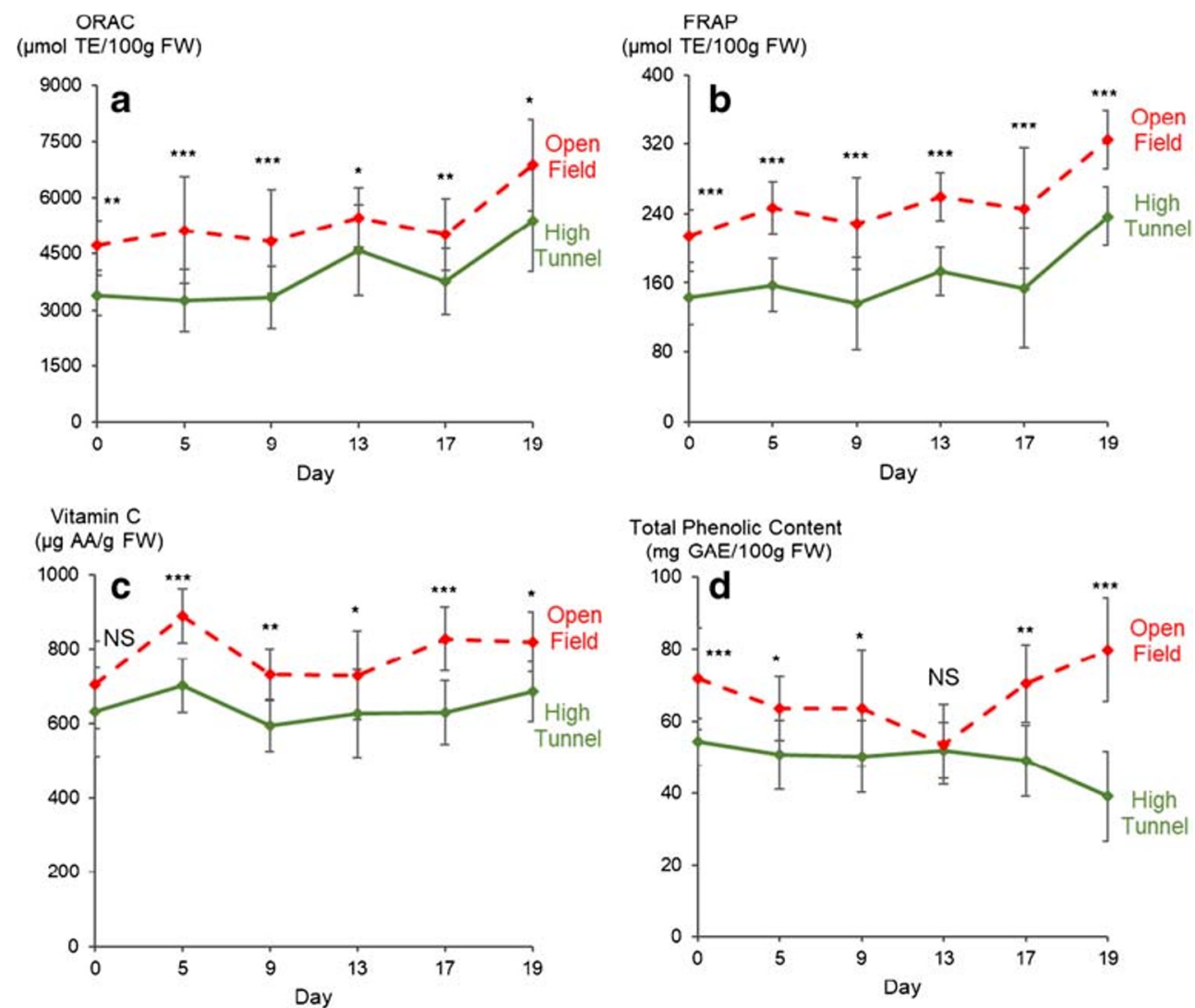
in the Central US and should be incorporated in resilient food systems.

\section{Conclusions}

The results of this study show that production of spinach in high tunnels can reduce the postharvest losses of this crop when stored in non-optimum temperatures, particularly as they relate to its physical quality. To our knowledge, this is the first study to report the effects of high tunnel production on the quality of spinach during postharvest storage. The spinach produced in both production systems was of superior quality as indicated by the physical and nutritional quality attributes measured on the day of harvest. There were no major differences between the spinach produced in the two production systems during storage at $3{ }^{\circ} \mathrm{C}$. However, the spinach produced in the high tunnels exhibited higher quality and longer shelf life when stored at $13{ }^{\circ} \mathrm{C}$, as indicated by reduced respiration rate, decreased yellowing rate, and higher water content. This indicates that high tunnel production systems could benefit small scale farming operations in the Central US that have been reporting limited access to cooling as one of their main challenges (Greater Kansas City Food Hub Working Group 2015). However, temperature control remains the most effective postharvest tool for maintaining the quality and extending the shelf life of fresh produce. Further research is needed for investigating the effect of the high tunnel production system on the crop and stress physiology of fresh produce for improving further the efficiency of this production system. Our research indicates that the high tunnel production system could contribute to the reduction of FLW from the field to the consumer and could be a valuable tool towards the efforts of achieving food security.

Acknowledgments The authors wish to thank Kimberly Oxley, Paul Andersen, Kelly Gude, and the Olathe Horticulture Research and Extension Center for assistance with this project. We also thank Dr. C.B. Rajashekar and Dr. Shehbaz Singh for their valuable advice during this project.

\section{Compliance with ethical standards}

Funding This work was supported by the USDA-National Institute of Food and Agriculture (NIFA) Agriculture and Food Research Initiative (AFRI) Food Security GRANT11451860.

Conflict of interest The authors declare that they have no conflict of interest.

Author contribution Conceptualization J.K.F., C.L.R., and E.D.P. Methodology H.S., J.K.F., C.L.R., and E.D.P. Investigation K.G.B and H.S. Formal analysis and data curation A.G.B. Visualization K.G.B. Supervision C.L.R. and E.D.P. Resources C.L.R. and E.D.P. Writingoriginal draft preparation K.G.B. Writing-review and editing J.K.F., C.L.R., and E.D.P. Funding acquisition J.K.F., C.L.R., and E.D.P.
Data availability The datasets generated during and/or analyzed during the current study are available from the corresponding author on reasonable request.

\section{References}

Agüero MV, Barg MV, Yommi A, Camelo A, Roura SI (2008) Postharvest changes in water status and chlorophyll content of lettuce (Lactuca sativa $L$.) and their relationship with overall visual quality. J Food Sci 73:S47-S55. https://doi.org/10.1111/j.1750-3841.2007.00604.x

Asfi M, Ouzounidou G, Moustakas M (2012) Evaluation of olive oil mill wastewater toxicity on spinach. Environ Sci Pollut Res 19:23632371. https://doi.org/10.1007/s11356-012-0746-y

Baldwin EA (2002) Fruit flavor, volatile metabolism and consumer perceptions. In: Knee M (ed) Fruit Quality and Its Biological Basis. CRC Press, Boca Raton, pp 89-106

Ballaré CL, Caldwell MM, Flint SD, Robinson SA, Bornman JF (2011) Effects of solar ultraviolet radiation on terrestrial ecosystems. Patterns, mechanisms, and interactions with climate change. Photochem Photobiol Sci 10:226-241. https://doi.org/10.1039/c0pp90035d

Bartz JA, Brecht JK (2002) Postharvest physiology and pathology of vegetables. CRC Press, Boca Raton

Batziakas KG (2019) Reducing food losses and improving the quality of locally produced spinach. $\mathrm{PhD}$ Thesis. Kansas State University

Batziakas KG, Talavera M, Swaney-Stueve M, Rivard CL, Pliakoni ED (2019) Descriptive analysis and consumer acceptability of locally and commercially grown spinach. J Food Sci 84:2261-2268. https:// doi.org/10.1111/1750-3841.14710

Batziakas KG, Rivard CL, Stanley H, Batziakas AG, Pliakoni ED (2020a) Reducing preharvest food losses in spinach with the implementation of high tunnels. Sci Hortic (Amsterdam) 265:109268. https://doi.org/10.1016/j.scienta.2020.109268

Batziakas KG, Singh S, Ayub K, Kang Q, Brecht JK, Rivard CL, Pliakoni ED (2020b) Reducing postharvest losses of spinach stored at nonoptimum temperatures with the implementation of passive modified atmosphere packaging. HortScience 55:326-335. https://doi.org/10. 21273/hortsci14732-19

Benzie IFF, Strain JJ (1996) The ferric reducing ability of plasma (FRAP) as a measure of "antioxidant power": the FRAP assay. Anal Biochem 239:70-76. https://doi.org/10.1006/abio.1996.0292

Bergquist SÅM, Gertsson UE, Olsson ME (2006) Influence of growth stage and postharvest storage on ascorbic acid and carotenoid content and visual quality of baby spinach (Spinacia oleracea L.). J Sci Food Agric 86:346-355. https://doi.org/10.1002/jsfa.2373

Bonasia A, Conversa G, Lazzizera C, Elia A (2019) Post-harvest performance of ready-to-eat wild rocket salad as affected by growing period, soilless cultivation system and genotype. Postharvest Biol Technol 156. https://doi.org/10.1016/j.postharvbio.2019.05.010

Borrelli K, Koenig RT, Jaeckel BM, Miles CA (2013) Yield of leafy greens in high tunnel winter production in the Northwest United States. HortScience 48:183-188. https://doi.org/10.21273/ HORTSCI.48.2.183

Buller T, Rivard C, Oxley K (2016) Growing under cover: a Kansas grower's guide. Kansas Rural Center, Topeka, Kansas

Campbell BM, Vermeulen SJ, Aggarwal PK, Corner-Dolloff C, Girvetz E, Loboguerrero AM, Ramirez-Villegas J, Rosenstock T, Sebastian L, Thornton PK, Wollenberg E (2016) Reducing risks to food security from climate change. Glob Food Sec 11:34 43. https://doi.org/ 10.1016/j.gfs.2016.06.002

Cantwell MI, Kasmire RF (2002) Postharvest handling systems: flower, leafy, and stem vegetable. In: Kader AA (ed) Postharvest Technology of Horticultural Crops. University of California Agriculture and Natural Resources, Davis, pp 423-435 
Cisneros-Zevallos L (2003) The use of controlled postharvest abiotic stresses as a tool for enhancing the nutraceutical content and adding-value of fresh fruits and vegetables. J Food Sci 68:1560 1565. https://doi.org/10.1111/j.1365-2621.2003.tb12291.x

Cowan JS, Miles CA, Andrews PK, Inglis DA (2014) Biodegradable mulch performed comparably to polyethylene in high tunnel tomato (Solanum lycopersicum L.) production. J Sci Food Agric 94:1854 1864. https://doi.org/10.1002/jsfa.6504

Ernst T, Drost D, Black B (2012) High tunnel winter spinach production. Utah State University Cooperative Extension

Espí E, Salmerón A, Fontecha A, García Y, Real AI (2006) Plastic films for agricultural applications. J Plast Film Sheeting 22:85-102. https://doi.org/10.1177/8756087906064220

Falamarzi Y, Palizdan N, Huang YF, Lee TS (2014) Estimating evapotranspiration from temperature and wind speed data using artificial and wavelet neural networks (WNNs). Agric Water Manag 140:2636. https://doi.org/10.1016/j.agwat.2014.03.014

Fouilleux E, Bricas N, Alpha A (2017) 'Feeding 9 billion people': global food security debates and the productionist trap. J Eur Public Policy 24:1658-1677. https://doi.org/10.1080/13501763.2017.1334084

Gil MI (2016) Preharvest factors and fresh-cut quality of leafy vegetables. Acta Hortic 1141:57-64. https://doi.org/10.17660/ActaHortic.2016. 1141.6

Glass G, Peckham P, Sanders J (1972) Consequences of failure to meet assumptions underlying the fixed effects analyses of variance and covariance. Rev Educ Res 42:237-288. https://doi.org/10.3102/ 00346543042003237

Grafton RQ, Daugbjerg C, Qureshi ME (2015) Towards food security by 2050. Food Secur 7:179-183. https://doi.org/10.1007/s12571-0150445-x

Greater Kansas City Food Hub Working Group (2015) Kansas City food hub feasibility study. Kansas City, MO

Gustavsson J, Cederberg C, Sonesson U, van Otterdijk R, Meybeck A (2011) Global food losses and food waste: extent, causes and prevention, international congress: save food! https://doi.org/10.1098/ rstb.2010.0126

Haytowitz DDB, Bhagwat S (2010) USDA database for the oxygen radical absorbance capacity (ORAC) of selected foods, release 2, US Department of Agriculture

Hewett EW (2006) Postharvest challenges for crops grown under protected cultivation. Acta Hortic 710:107-112. https://doi.org/10. 17660/ActaHortic.2006.710.8

Hodges DM, DeLong JM (2007) The relationship between antioxidants and postharvest storage quality of fruits and vegetables. Stewart Postharvest Rev 3:1-9. https://doi.org/10.2212/spr.2007.3.12

Hodges DM, Forney CF (2003) Postharvest ascorbate metabolism in two cultivars of spinach differing in their senescence rates. J Am Soc Hortic Sci 128:930-935. https://doi.org/10.21273/JASHS.128.6.0930

Hodges DM, Lester GE, Munro KD, Toivonen PMA (2004) Oxidative stress: importance for postharvest quality. HortScience:924-929. https://doi.org/10.21273/HORTSCI.39.5.924

Hoppenstedt ZN, Griffin JJ, Pliakoni ED, Rivard CL (2019) Yield, quality, and performance of organic sweetpotato slips grown in high tunnel compared with open field. Horttechnology 29:140-150. https://doi.org/10.21273/horttech04139-18

Huché-Thélier L, Crespel L, Le Gourrierec J, Morel P, Sakr S, Leduc N (2016) Light signaling and plant responses to blue and UV radiationsperspectives for applications in horticulture. Environ Exp Bot 121:2238. https://doi.org/10.1016/j.envexpbot.2015.06.009

Hung Y-C (1993) Latent damage-a systems perspective. In: Shewfelt RL, Prussia SE (eds) Postharvest Handling: A Systems Approach. Academic Press Inc, San Diego, pp 211-224. https://doi.org/10. 1016/b978-0-08-092576-9.50010-0

Iwanzik W, Tevini M, Dohnt G, Voss M, Weiss W, Gräber P, Renger G (1983) Action of UV-B radiation on photosynthetic primary reactions in spinach chloroplasts. Physiol Plant 58:401-407. https://doi.org/10.1111/j.1399-3054.1983.tb04201.x

Jacxsens L, Devlieghere F, Debevere J (1999) Validation of a systematic approach to design equilibrium modified atmosphere packages for fresh-cut produce. LWT Food Sci Technol 32:425-432. https://doi. org/10.1006/fstl.1999.0558

Jedermann R, Nicometo M, Uysal I, Lang W (2014) Reducing food losses by intelligent food logistics. Philos Trans R Soc A Math Phys Eng Sci 372: 20130302. https://doi.org/10.1098/rsta.2013.0302

Jett LW (2017) High tunnels. In: Orzolek MD (ed) A Guide to the Manufacture, Performance, and Potential of Plastics in Agriculture. Elsevier, Amsterdam, pp 107-116. https://doi.org/10. 1016/b978-0-08-102170-5.00006-3

Johnson JR, McGuinn JR, Rushing JW (1989) Influence of preharvest factors on postharvest quality of prepackaged fresh market spinach. Appl Agric Res 4:141-143

Kader AA (2000) Pre-and postharvest factors affecting fresh produce quality, nutritional value, and implications for human health. In: Intl. Congress Food Prod. and Th. pp. 109-119

Kader AA (2002) Postharvest technology and biology: an overview. In: Kader AA (ed) Postharvest Technology of Horticultural Crops. University of California Agriculture and Natural Resources, Davis, pp 39-47

Kader AA (2005) Increasing food availability by reducing postharvest losses of fresh produce. Acta Hortic 682:2169-2176. https://doi.org/ 10.17660/ActaHortic.2005.682.296

Klimczak I, Gliszczynska-wiglo A (2015) Comparison of UPLC and HPLC methods for determination of vitamin C. Food Chem 175: 100-105. https://doi.org/10.1016/j.foodchem.2014.11.104

Knewtson SJB, Carey EE, Kirkham MB (2010) Management practices of growers using high tunnels in the central great plains of the United States. Horttechnology 20:639-645. https://doi.org/10.21273/ HORTTECH.20.3.639

Koike ST, Cahn M, Cantwell M, Fennimore S, Lestrange M, Natwick E, Smith RF, Takele E (2011) Spinach production in California. University of California, Agriculture and Natural Resources. https://doi.org/10.3733/ucanr.7212

Lamont WJ (2009) Overview of the use of high tunnels worldwide. Horttechnology 19:25-29. https://doi.org/10.21273/HORTSCI.19.1.25

Lareo C, Ares G, Ferrando L, Lema P, GÁmbaro A, Soubes M (2009) Influence of temperature on shelf life of butterhead lettuce leaves under passive modified atmosphere packaging. J Food Qual 32: 240-261. https://doi.org/10.1111/j.1745-4557.2009.00248.x

Lipinsky B, Hanson C, Lomax J, Kitinoja L, Waite R, Seachinger T (2013) Reducing food loss and waste. Working paper. Installment 2 of "Creating a sustainable food future". World Resources Institute

Lix LM, Keselman JC, Keselman HJ (2008) Consequences of assumption violations revisited: a quantitative review of alternatives to the one-way analysis of variance F test. Rev Educ Res 66:579-619. https://doi.org/10.3102/00346543066004579

Machado RMA, Alves-Pereira I, Ferreira RMA (2018) Plant growth, phytochemical accumulation and antioxidant activity of substrategrown spinach. Heliyon 4:e00751. https://doi.org/10.1016/j. heliyon.2018.e00751

Manzocco L (2016) The acceptability limit in food shelf life studies. Crit Rev Food Sci Nutr 56:1640-1646. https://doi.org/10.1080/ 10408398.2013.794126

Martínez-Sánchez A, Lozano-Pastor P, Artés-Hernández F, Artés F, Aguayo E (2019) Preharvest UV-C treatment improves the quality of spinach primary production and postharvest storage. Postharvest Biol Technol 155:130-139. https://doi.org/10.1016/j.postharvbio.2019.05.021

McGuire RG (1992) Reporting of objective color measurements. HortScience 27:1254-1255. https://doi.org/10.21273/hortsci.27.12. 1254

Medina MS, Tudela JA, Marín A, Allende A, Gil MI (2012) Short postharvest storage under low relative humidity improves quality and shelf 
life of minimally processed baby spinach (Spinacia oleracea L.). Postharvest Biol Technol 67:1-9. https://doi.org/10.1016/j. postharvbio.2011.12.002

Morelock TE, Correll JC (2008) Spinach. In: Prohens J, Nuez F (eds) Vegetables I. Springer, New York, pp 189-218

Myers SS, Smith M, Guth S, Golden C, Vaitla B, Mueller N, Dangour AD, Huybers P (2017) Climate change and global food systems: potential impacts on food security and undernutrition. Annu Rev Public Health 38:259-277. https://doi.org/10.1146/annurevpublhealth-031816-044356

O'Connell S, Rivard C, Peet MM, Harlow C, Louws F (2012) High tunnel and field production of organic heirloom tomatoes: yield, fruit quality, disease, and microclimate. HortScience 47:12831290. https://doi.org/10.21273/hortsci.47.9.1283

Orde KM, Eaton C, Sideman RG (2018) Yield and soluble solids content of winter-grown spinach in unheated high tunnels in New England. HortScience 53:638-645. https://doi.org/10.21273/hortsci12956-18

Palonen P, Pinomaa A, Tommila T (2017) The influence of high tunnel on yield and berry quality in three floricane raspberry cultivars. Sci Hortic (Amsterdam) 214:180-186. https://doi.org/10.1016/j.scienta. 2016.11.049

Pandjaitan N, Howard LR, Morelock T, Gil MI (2005) Antioxidant capacity and phenolic content of spinach as affected by genetics and maturation. J Agric Food Chem 53:8618-8623. https://doi.org/10. 1021/jf052077i

Pandrangi S, LaBorde LF (2004) Retention of folate, carotenoids, and other quality characteristics in commercially packaged fresh spinach. J Food Sci 69:C702-C707. https://doi.org/10.1111/j.13652621.2004.tb09919.x

Plaxton WC, Podestá FE (2006) The functional organization and control of plant respiration. CRC Crit Rev Plant Sci 25:159-198. https://doi. org/10.1080/07352680600563876

Porat R, Lichter A, Terry LA, Harker R, Buzby J (2018) Postharvest losses of fruit and vegetables during retail and in consumers' homes: quantifications, causes, and means of prevention. Postharvest Biol Technol 139:135-149. https://doi.org/10.1016/j.postharvbio.2017. 11.019

Prakash A, Guner AR, Caporaso F, Foley DM (2000) Effects of low-dose gamma irradiation on the shelf life and quality characteristics of cut romaine lettuce packaged under modified atmosphere. J Food Sci 65:549-553. https://doi.org/10.1111/j.1365-2621.2000.tb16046.x

Prior RL, Hoang H, Gu L, Wu X, Bacchiocca M, Howard L, HampschWoodill M, Huang D, Ou B, Jacob R (2003) Assays for hydrophilic and lipophilic antioxidant capacity (oxygen radical absorbance capacity (ORACFL)) of plasma and other biological and food samples. J Agric Food Chem 51:3273-3279. https://doi.org/10.1021/ jf0262256

Proulx E, Yagiz Y, Cecilia M, Emond JP (2010) Quality attributes limiting snap bean (Phaseolus vulgaris L.) postharvest life at chilling and non-chilling temperatures. HortScience 45:1238-1249. https://doi. org/10.21273/HORTSCI.45.8.1238

Prusky D (2011) Reduction of the incidence of postharvest quality losses, and future prospects. Food Secur 3:463-474. https://doi.org/10. 1007/s12571-011-0147-y

Rogers MA, Burkness EC, Hutchison WD (2016) Evaluation of high tunnels for management of Drosophila suzukii in fall-bearing red raspberries: potential for reducing insecticide use. J Pest Sci 89: 815-821. https://doi.org/10.1007/s10340-016-0731-1

Romig WR (1995) Selection of cultivars for lightly processed fruits and vegetables. HortScience 30:38-40. https://doi.org/10.21273/hortsci. 30.1 .38

Sams CE (1999) Preharvest factors affecting postharvest texture. Postharvest Biol Technol 15:249-254. https://doi.org/10.1016/ S0925-5214(98)00098-2
Shewfelt RL, Prussia SE, Sparks SA (2014) Challenges in handling fresh fruits and vegetables. In: Florkowski WJ, Shewfelt RL, Brueckner B, Prussia SE (eds) Postharvest Handling: A Systems Approach. Academic Press Inc., San Diego, pp 11-30. https://doi.org/10. 1016/C2012-0-03264-4

Singleton VL, Rossi JAJ (1965) Colorimetry of total phenolics with phosphomolybdic-phosphotungstic acid reagents. Am J Enol Vitic 16:144-158. https://doi.org/10.12691/ijebb-2-1-5

Suslow TV, Cantwell M (1999) Spinach: recommendations for maintaining postharvest quality [WWW document]. UC Davis Veg. Prod. facts.http://postharvest.ucdavis.edu/Commodity_Resources/Fact Sheets/Datastores/Vegetables_English/?uid=32\&ds=799. Accessed 1 Oct 2020

Suweis S, Carr JA, Maritana A, Rinaldo A, D'Odorico P (2015) Resilience and reactivity of global food security. Proc Natl Acad Sci U S A 112:6902-6907. https://doi.org/10.1073/pnas. 1507366112

Tilman D, Balzer C, Hill J, Befort BL (2011) Global food demand and the sustainable intensification of agriculture. Proc Natl Acad Sci U S A 108:20260-20264. https://doi.org/10.1073/pnas.1116437108

Toivonen PM (2003) Effects of storage conditions and postharvest procedures on oxidative stress in fruits and vegetables. In: Hodges DM (ed) Postharvest Oxidative Stress in Horticultural Crops. The Haworth Press Inc, New York, pp 69-90

Tudela JA, Marín A, Martínez-Sánchez A, Luna MC, Gil MI (2013) Preharvest and postharvest factors related to off-odours of freshcut iceberg lettuce. Postharvest Biol Technol 86:463-471. https:// doi.org/10.1016/j.postharvbio.2013.07.028

Vescera M, Brown RN (2019) Effects of three production systems on muskmelon yield and quality in New England. HortScience 51:510 517. https://doi.org/10.21273/hortsci.51.5.510

Watkins CB, Nock DJ (2012) Production guide for storage of organic fruits and vegetables, New York State Department of Agriculture \& Markets NYS IPM Publication No 10

Wellburn AR (1994) The spectral determination of chlorophylls a and b, as well as total carotenoids, using various solvents with spectrophotometers of different resolution. J Plant Physiol 144:307-313. https://doi.org/10.1016/S0176-1617(11)81192-2

Weston LA, Barth MM (1997) Preharvest factors affecting postharvest quality of vegetables. HortScience 32:812-816. https://doi.org/10. 21273/HORTSCI.32.5.812

Yamauchi N, Watada AE (1991) Regulated chlorophyll degradation in spinach leaves during storage. J Am Soc Hortic Sci 116:58-62. https://doi.org/10.21273/jashs.116.1.58

Zhao X, Carey E (2009) Summer production of lettuce, and microclimate in high tunnel and open field plots in Kansas. Horttechnology 19: 113-119. https://doi.org/10.21273/HORTSCI.19.1.113

Zhao X, Carey EE, Young JE, Wang W, Iwamoto T (2007a) Influences of organic fertilization, high tunnel environment, and postharvest storage on phenolic compounds in lettuce. HortScience 42:71-76. https://doi.org/10.21273/HORTSCI.42.1.71

Zhao X, Iwamoto T, Carey EE (2007b) Antioxidant capacity of leafy vegetables as affected by high tunnel environment, fertilisation and growth stage. J Sci Food Agric 87:2692-2699. https://doi.org/10. $1002 /$ jsfa.3032

Publisher's note Springer Nature remains neutral with regard to jurisdictional claims in published maps and institutional affiliations.

This manuscript is a portion of a Ph.D. Thesis (Batziakas 2019) submitted to Kansas State University, Manhattan, Kansas, USA. 